\title{
Bermudagrass Resistance to Spring Dead Spot Caused by Ophiosphaerella herpotricha
}

J. H. Baird, Assistant Professor, Department of Crop and Soil Sciences, Michigan State University, East Lansing 48824-1325; D. L. Martin, Associate Professor, Department of Horticulture and Landscape Architecture, C. M. Taliaferro, Professor, Department of Plant and Soil Sciences, and M. E. Payton, Associate Professor, Department of Statistics, Oklahoma State University, Stillwater 74078-6027; and N. A. Tisserat, Professor, Department of Plant Pathology, Kansas State University, Manhattan 66506-5506

\begin{abstract}
Baird, J. H., Martin, D. L., Taliaferro, C. M., Payton, M. E., and Tisserat, N. A. 1998. Bermudagrass resistance to spring dead spot caused by Ophiosphaerella herpotricha. Plant Dis. 82:771774.

Field and greenhouse studies were conducted to evaluate the resistance of seed- and vegetatively propagated bermudagrass entries (Cynodon spp.) to spring dead spot caused by Ophiosphaerella herpotricha. In Kansas greenhouse studies, $O$. herpotricha caused root discoloration and root weight reductions in all entries tested. However, in Kansas field plots, root weight reductions were not different among entries and were not correlated with disease severity ratings. In an inoculated field study in Oklahoma, diseased areas ranged from $47 \mathrm{~cm}^{2}$ for the entry Jackpot to $262 \mathrm{~cm}^{2}$ for Poco Verde in 1995 , and from 121 to $1,810 \mathrm{~cm}^{2}$ for the entries Guymon and Common in 1996. African bermudagrass (Cynodon transvaalensis) exhibited the greatest number of live shoots per diseased area in both years, due in part to its greater shoot density, but also indicating greater potential to recover from the disease. African bermudagrass, Guymon, Sundevil, Midlawn, Midfield, Ft. Reno, Mirage, and several experimental seed-propagated entries were most resistant to spring dead spot, having the lowest diseased area and greatest number of live shoots within diseased areas. In Oklahoma, severity of spring dead spot among bermudagrass entries was correlated with feeeze injury that occurred during the first winter after planting.
\end{abstract}

Additional keywords: Cynodon dactylon, Ophiosphaerella korrae

Spring dead spot (SDS) is a common and often serious disease of bermudagrass (Cynodon dactylon and $C$. dactylon $\times C$. transvaalensis) in North America and Australia $(13,14,17)$. Symptoms appear in early spring as dormant bermudagrass resumes growth and occur as circular, dead areas ranging from a few centimeters up to several meters in diameter. In severe cases, dead areas coalesce to encompass a much larger area of turf, which may be mistaken for winter kill or winter desiccation. Bermudagrass regrowth into dead areas is often slow and usually follows weed invasion. SDS is primarily a disease of mature stands of bermudagrass (usually 3 or more years old) that are intensively managed at low mowing heights and high nitrogen fertility. High incidences of SDS have been noted on turf that received heavy applica-

Corresponding author: J. H. Baird

E-mail: jhbaird@pilot.msu.edu

Contribution of the Oklahoma Agric. Exp. Stn. Project 2264 and the Kansas Agric. Exp. Stn. 97299-J.

Accepted for publication 18 March 1998.

Publication no. D-1998-0420-03R

(C) 1998 The American Phytopathological Society tions of nitrogen in late summer and fall (11).

SDS is caused by at least three different ectotrophic, root-rotting fungi. Ophiosphaerella korrae (=Leptosphaeria korrae) and $L$. narmari incite the disease in Australia $(14,17)$; whereas $O$. herpotricha and $O$. korrae have been reported to cause symptoms in North America $(3,5,16)$. The geographic distribution of these SDS pathogens in North America is still not clear, although isolations from SDS patches in Kansas, Oklahoma, and Texas suggest that $O$. herpotricha is the primary cause of SDS in the southern Great Plains region (16). $O$. korrae has only recently been isolated (1995) from symptomatic bermudagrass in Oklahoma (N. A. Tisserat, unpublished data).

The severity of SDS can be reduced, although not necessarily eliminated, by cultural practices (11). Avoidance of heavy, late-season nitrogen fertilization, insurance of adequate drainage, and reduction of soil compaction and thatch help suppress symptoms. Ammonium-based nitrogen and potassium fertility programs also have been shown to reduce disease severity $(4,12)$. Several fungicides are labeled for control of SDS; however, disease control often has been inconsistent. Also, fungicides must be applied in fall and winter, and sometimes early spring, before symptoms are present $(10,13)$.

A promising approach to management of SDS disease may be the use of resistant bermudagrass cultivars. Furthermore, because SDS severity is often enhanced by cold temperatures, cold-hardy bermudagrass cultivars may be better able to resist the disease $(11,16)$. At Oklahoma State University, a breeding project is ongoing to develop seed- and vegetatively propagated bermudagrass cultivars with superior winter hardiness, turf quality characteristics, and disease resistance. The purpose of this study was to evaluate commercial and experimental bermudagrass entries for resistance to SDS in the greenhouse and the field.

\section{MATERIALS AND METHODS}

Greenhouse experiments. In Kansas, bermudagrass entries (Table 1) were inoculated in the greenhouse to determine their susceptibility to $O$. herpotricha. Stolons, 2 to $5 \mathrm{~cm}$ long, were collected from bermudagrass in field plots in Wichita. Stolons were surface-sterilized for 3 $\min$ in $0.5 \% \mathrm{NaOCl}$, rinsed in distilled water, and placed in pots $(20 \mathrm{~cm}$ diameter $)$ containing a steamed soil:perlite:sand mixture (1:1:1 vol/vol/vol). Sample stolon pieces were placed on acidified potato dextrose agar (APDA), but no ectotrophic fungi were recovered. After establishment, five stolon pieces (each approximately 2 $\mathrm{cm}$ long), each containing at least one shoot, were transferred to a $6 \times 25 \mathrm{~cm}$ Cone-tainer and allowed to grow for 4 months. Five pots of each bermudagrass entry were then inoculated by inserting 3 $\mathrm{g}$ of oats infested with $O$. herpotricha (KS28) per pot into the soil surrounding roots and stolons. Oat inoculum was prepared as previously described (16). Soil in five additional pots of each entry was amended with $3 \mathrm{~g}$ of sterile oats as controls. Pots were placed in the greenhouse in a randomized complete block factorial (bermudagrass entry $\times$ inoculum) arrangement with five replicates. Plants were fertilized at the start of the experiment with $4 \mathrm{~g}$ of Osmocote 14-14-14 (Sierra Chemical Co., Milpitas, CA) and watered daily as needed. Air temperatures during the experiment ranged from 15 to $30^{\circ} \mathrm{C}$. 
Plants were maintained in the greenhouse for 120 days, then washed with water to remove soil from roots. Roots were rated for the percentage of root surface area discolored by $O$. herpotricha as an indication of the amount of root rot present. Roots were then oven-dried for $96 \mathrm{~h}$ at $50^{\circ} \mathrm{C}$ and weighed. Since bermudagrass roots in all pots amended with sterile oats exhibited $<5 \%$ discoloration, root discoloration percentages were compared only among entries inoculated with $O$. herpotricha. Root weight reductions resulting from inoculations were determined by subtracting the root weight of inoculated from noninoculated plants in each block, dividing by the root weight of the noninoculated plants, and multiplying by 100 . Data were subjected to analysis of variance, and means were separated using Fisher's (protected) least significant difference $(L S D)$ test $($ alpha $=0.05)(15)$. The experiment was conducted twice.

Field experiments. Sixteen entries of bermudagrass (Table 1) were established from stolons or seed at the Kansas State University Horticultural Research Center, Wichita, in a Canadian Aldeck sandy loam in May 1986. Selections were planted in 3 $\times 3 \mathrm{~m}$ plots in a randomized complete block design with three replicates. Many of the entries did not survive more than 1 or 2 years because of winter kill. In a second study, 26 bermudagrass entries (Table 1) were established at the Oklahoma State University Turfgrass Research Center, Stillwater, in August 1993. Twenty-three of the bermudagrass entries were established from seed at a rate of $49 \mathrm{~kg}$ of pure live seed per ha, and three bermudagrass entries were established vegetatively from 8 -cm-diameter plugs established on $30-\mathrm{cm}$ centers on a Kirkland silt loam in $1.5 \times 3.0$ $\mathrm{m}$ plots arranged as previously described. Upon plot establishment at both sites, the turf was maintained at a $1.3-\mathrm{cm}$ mowing height, with mowing performed three times per week using a reel mower. The turf received $49 \mathrm{~kg} \mathrm{~N} / \mathrm{ha} / \mathrm{month}$ from May through September throughout the experi-

Table 1. Bermudagrass entries tested for reaction to Ophiosphaerella herpotricha

\begin{tabular}{|c|c|c|c|}
\hline Entry & Species & Origin/source & Location tested \\
\hline \multicolumn{4}{|l|}{ Commercial seeded } \\
\hline Common & Cynodon dactylon & Arizona & KS, OK \\
\hline Poco Verde & C. dactylon & Desert Sun Marketing Co. & OK \\
\hline NuMex Sahara & C. dactylon & Farmers Marketing Corp. & OK \\
\hline Primavera & C. dactylon & Farmers Marketing Corp. & $\mathrm{OK}$ \\
\hline NMS-4 & C. dactylon & Farmers Marketing Corp. & KS \\
\hline Cheyenne & C. dactylon & Jacklin Seed Co. & $\mathrm{OK}$ \\
\hline Jackpot & C. dactylon & Jacklin Seed Co. & OK \\
\hline Sundevil & C. dactylon & Jacklin Seed Co. & OK \\
\hline Sonesta & C. dactylon & Scotts Co. & $\mathrm{KS}, \mathrm{OK}$ \\
\hline NM-72 & C. dactylon & New Mexico State University & KS \\
\hline Guymon & C. dactylon & Johnston Seed Co. & OK \\
\hline Mirage & C. dactylon & International Seeds, Inc. & OK \\
\hline Pyramid & C. dactylon & International Seeds, Inc. & OK \\
\hline Tropica & C. dactylon & Turf Merchants & OK \\
\hline $\mathrm{C}^{2}$ & C. dactylon & Finelawn Research & OK \\
\hline \multicolumn{4}{|l|}{ Experimental seeded } \\
\hline $\begin{array}{l}\text { OKS ( } 8 \text { numbered } \\
\text { entries) }\end{array}$ & C. dactylon & Oklahoma State University & OK \\
\hline Ft. Reno & C. dactylon & Oklahoma State University & OK \\
\hline African bermudagrass & C. transvaalensis & Oklahoma State University & OK \\
\hline \multicolumn{4}{|c|}{ Experimental vegetative } \\
\hline A-29 & $\begin{array}{l}\text { C. dactylon } \times \\
\text { C. transvaalensis }\end{array}$ & Kansas State University & $\mathrm{KS}$ \\
\hline \multicolumn{4}{|l|}{ Commercial vegetative } \\
\hline Midlawn & $\begin{array}{l}\text { C. dactylon } \times \\
\text { C. transvaalensis }\end{array}$ & $\begin{array}{l}\text { Kansas State University } \\
\text { Research Foundation }\end{array}$ & $\mathrm{KS}$, OK \\
\hline Midfield & $\begin{array}{l}\text { C. dactylon } \times \\
\text { C. transvaalensis }\end{array}$ & $\begin{array}{l}\text { Kansas State University } \\
\text { Research Foundation }\end{array}$ & KS, OK \\
\hline Midiron & $\begin{array}{l}\text { C. dactylon } \times \\
\text { C. transvaalensis }\end{array}$ & $\begin{array}{l}\text { Kansas State University } \\
\text { Research Foundation }\end{array}$ & KS \\
\hline MS-Choice & $\begin{array}{l}\text { C. dactylon } \times \\
\text { C. transvaalensis }\end{array}$ & Mississippi State University & $\mathrm{KS}$ \\
\hline Tifgreen & $\begin{array}{l}\text { C. dactylon } \times \\
\text { C. transvaalensis }\end{array}$ & USDA/ARS, Tifton, GA & $\mathrm{KS}$ \\
\hline Tifway (II) & $\begin{array}{l}\text { C. dactylon } \times \\
\text { C. transvaalensis }\end{array}$ & USDA/ARS, Tifton, GA & KS \\
\hline Texturf 10 & C. dactylon & Texas A\&M University & KS \\
\hline Vamont & C. dactylon & $\begin{array}{l}\text { Virginia Polytechnic \& State } \\
\text { University }\end{array}$ & $\mathrm{KS}$ \\
\hline Tufcote & C. dactylon & $\begin{array}{l}\text { National Plant Materials } \\
\text { Center, Beltsville, MD }\end{array}$ & $\mathrm{KS}$ \\
\hline Tifton 10 & C. dactylon & USDA/ARS, Tifton, GA & OK \\
\hline Quickstand Common & C. dactylon & University of Kentucky & KS \\
\hline
\end{tabular}

ments. Soil acidity was 6.8 , and $\mathrm{P}$ and $\mathrm{K}$ were maintained at adequate levels for turf growth.

Bermudagrass entries in Wichita were inoculated with a mixture of four Kansas isolates (KS2, KS3, KS11, and KS23) of O. herpotricha in September 1987; whereas a single isolate from Stillwater (KS188) was used to inoculate plots in Oklahoma in September 1994. In Wichita, two soil-turf plugs were removed to a depth of $10 \mathrm{~cm}$ from each plot using a standard $10-\mathrm{cm}$-diameter $\left(84-\mathrm{cm}^{2}\right.$ area) golf cup cutter. Ten grams of nondried infested oats was placed into one of the holes; the remaining hole was amended with 10 grams of sterile oats. The plugs were then replaced, and the turf was irrigated to prevent desiccation. Inoculations in Stillwater were identical except that six soil-turf plugs were removed from each plot; three were inoculated with $O$. herpotricha-infested oats, and three were treated with sterile oats. Plugged areas within each plot were mapped in order to monitor disease development during subsequent years.

Disease evaluations in Wichita were made in May 1989 and 1991. Disease ratings were not taken in 1990 because of extensive winter damage to many entries. Because plots had a high level of natural infection in addition to symptoms at the inoculation site, each bermudagrass plot was rated visually for the percent area damaged by spring dead spot.

Winter kill ratings were made in April 1994 in Stillwater. A $0.5 \times 0.5 \mathrm{~m}$ grid containing 48 contact points was randomly tossed twice onto each plot. Percent winter kill was determined by dividing the number of contact points intersecting live green shoots by 48 . In addition, bermudagrass green up was determined visually on a 1 to 9 scale, where $1=$ dead or dormant turf and $9=$ completely green, healthy turf. SDS evaluations were made during bermudagrass green up in April 1995 and 1996 and when disease symptoms were most prominent. The spots completely recovered in May with the onset of rapid bermudagrass growth. The diameter of each necrotic spot was measured in two directions, and the averaged value was used to calculate each area of disease. Values reported for diseased area represent the average of the three inoculated areas taken per replication for a total of nine area measurements taken per entry.

Winter kill, green up, and disease area data were subjected to analysis of variance, and means were separated using Fisher's protected LSD test $($ alpha $=0.05)(15)$. The numbers of live shoots contained within the SDS areas were counted at the same time as the area measurements were made. Data were subjected to analysis of covariance (15). The number of shoots within a $46-\mathrm{cm}^{2}$ plug was determined for each bermudagrass treatment during July 1996 and was used as the covariate in the analysis. 
This was done in order to account for differences in live shoot counts that were due to differences in turf density inherent within each entry and not attributable to disease recuperative capacity.

\section{RESULTS}

In Kansas, O. herpotricha caused significant root discoloration to all bermudagrass entries tested in the greenhouse. Alwere detected among inoculated bermudagrass entries, these ratings were not correlated $(r=0.03)$ with root weight reductions (Table 2). Therefore, root discoloration ratings may more accurately reflect a combination of both ectotrophic fungal growth and root or stolon rot. Root discoloration and weight reductions in the greenhouse also were not consistent with disease severity ratings in field plots in 1989 or 1991 (Table 2). For example, the entries Midiron and Tifgreen had similar disease severity ratings in the greenhouse but were significantly different in susceptibility to SDS in the field. A second greenhouse study (data not shown) also showed extensive root discoloration and weight reduction in all bermudagrass entries 4 months after inoculation with $O$. herpotricha, but these ratings were not consistent with field observations. Therefore, the greenhouse inoculation techniques we used were not useful in predicting the relative resistance of bermudagrass entries to SDS.

In Oklahoma, African bermudagrass, Guymon, Midlawn, and several Oklahoma State seed-propagated entries were least affected by winter temperatures following though differences in root discoloration

establishment (Table 3). In general, bermudagrass cultivars, especially seedpropagated cultivars, are most susceptible to freeze injury during the first winter after establishment. All entries recovered from freeze injury resulting during the winter of 1993-94. No apparent injury occurred during the winters of 1994-95 or 1995-96.

SDS symptoms in Oklahoma were observed 7 months (April 1995) after inoculation (Table 4). All of the bermudagrass entries showed some symptoms after inoculation, but no symptoms were observed in areas inoculated with sterile oats. Disease severity was greater in 1996 than in 1995; however, relative disease resistance among the entries was consistent for both years. African bermudagrass, Guymon, Sundevil, Midlawn, Midfield, Ft. Reno, Mirage, and several Oklahoma State seedpropagated entries exhibited the greatest resistance to SDS in terms of area of diseased turf. Conversely, dead spots in the susceptible entry Common expanded to greater than 20 times the original area of inoculation within 2 years. Disease ratings were consistent with those bermudagrass entries common to both the Kansas and Oklahoma field studies (Tables 2 and 4).

Inherent shoot density of African bermudagrass ranged from 2.5 to 5 times greater than the other bermudagrass entries (data not shown). Consequently, the greatest number of live shoots was counted within the diseased areas of African bermudagrass even though the data were adjusted for shoot density (Table 5). Furthermore, disease severity in 1995

Table 2. Severity of spring dead spot in the greenhouse and in the field in bermudagrass entries following inoculation with Ophiosphaerella herpotricha in Kansas

\begin{tabular}{|c|c|c|c|c|}
\hline \multirow[b]{3}{*}{ Entry } & \multicolumn{2}{|c|}{ Greenhouse inoculations } & \multirow{2}{*}{\multicolumn{2}{|c|}{$\begin{array}{c}\text { Field inoculations } \\
(\% \text { plot area damaged })^{\mathrm{z}}\end{array}$}} \\
\hline & \multirow{2}{*}{$\begin{array}{c}\% \text { root weight } \\
\text { reduction }^{x}\end{array}$} & \multirow{2}{*}{$\begin{array}{c}\text { Root } \\
\text { discoloration }\end{array}$} & & \\
\hline & & & 1989 & 1991 \\
\hline Midiron & 17.2 & 50 & 0 & 4.0 \\
\hline Midlawn & 38.5 & 52 & 0.8 & 6.2 \\
\hline Midfield & 32.0 & 50 & 0.6 & 7.8 \\
\hline A-29 & 8.9 & 60 & 1.1 & 12.9 \\
\hline Quickstand Common & 18.8 & 64 & 0.4 & 20.6 \\
\hline Texturf 10 & 6.8 & 60 & 2.2 & 24.7 \\
\hline Vamont & 13.2 & 64 & 2.2 & 24.7 \\
\hline Tifgreen & 24.8 & 48 & 4.0 & 36.1 \\
\hline Tufcote & 31.4 & 56 & 0.7 & Winter kill \\
\hline MS-Choice & -2.0 & 56 & 1.8 & Winter kill \\
\hline Tifway II & 26.8 & 44 & 2.5 & Winter kill \\
\hline Tifway & 9.8 & 44 & 3.6 & Winter kill \\
\hline NM-72 & 28.2 & 48 & Winter kill & Winter kill \\
\hline Sonesta & 20.6 & 64 & Winter kill & Winter kill \\
\hline NMS-4 & 10.0 & 64 & Winter kill & Winter kill \\
\hline Common & 54.6 & 64 & Winter kill & Winter kill \\
\hline $\operatorname{LSD}(0.05)$ & NS & 15 & 2.1 & 14.7 \\
\hline
\end{tabular}

${ }^{\mathrm{x}}$ Root weight reductions determined by subtracting the root weights of inoculated from noninoculated plants within the same block, dividing by the root weight of the noninoculated plants, and multiplying by 100 . Negative values in the table represent a net increase in root weight following inoculation.

${ }^{\mathrm{y}}$ Mean percent root discoloration 120 days after inoculation. Roots on all bermudagrass entries amended with sterile oats exhibited $<5 \%$ root discoloration and were not included in the analysis.

${ }^{\mathrm{z}}$ Percent plot area damaged determined visually in May 1989 and 1990. Those entries that could not be rated for spring dead spot damage because of severe winter injury are indicated. correlated with winter kill severity and green up in 1994 (Table 6).

\section{DISCUSSION}

The lack of correlation between greenhouse and field SDS ratings noted in this study and by Crahay et al. (3) following inoculations with $O$. korrae suggests that factors other than direct colonization and rotting of roots influence disease severity. Extensive root rot of bermudagrass after prolonged exposure to the fungus at optimal temperatures for disease in the greenhouse probably does not accurately reflect disease development in the field. Nus and Shashikumar (12) reported that root colonization by $O$. herpotricha and $O$. korrae reduced freezing resistance of bermudagrass. We did not attempt to evaluate the susceptibility of bermudagrass genotypes to $O$. korrae because this fungus was only recently identified in Oklahoma, and it did not occur in plots. Therefore, disease severity ratings we report here may vary in other regions of the United States or Australia where $O$. korrae or $L$. narmari are the primary pathogens.

Table 3. Green up and winter kill evaluations for bermudagrass entries in April 1994 following planting in August 1993 in Oklahoma

\begin{tabular}{|c|c|c|}
\hline Entry & Green up ${ }^{w}$ & $\begin{array}{c}\text { Winter kill } \\
(\%)\end{array}$ \\
\hline Common & 1 & 98 \\
\hline Poco Verde & 1 & 98 \\
\hline Jackpot & 2 & 92 \\
\hline Sonesta & 2 & 98 \\
\hline Tifton $10^{x}$ & 5 & $\ldots{ }^{y}$ \\
\hline Primavera & 1 & 98 \\
\hline $\mathrm{OKS}^{\mathrm{z}}$ 91-1 & 2 & 94 \\
\hline NuMex Sahara & 2 & 98 \\
\hline Pyramid & 2 & 95 \\
\hline Cheyenne & 2 & 94 \\
\hline Tropica & 1 & 95 \\
\hline OKS 91-2 & 2 & 84 \\
\hline $\mathrm{C}^{2}$ & 1 & 98 \\
\hline OKS 91-6 & 3 & 79 \\
\hline Mirage & 3 & 60 \\
\hline Ft. Reno & 5 & 39 \\
\hline Midfield $^{x}$ & 5 & $\ldots y$ \\
\hline OKS 91-13 & 5 & 46 \\
\hline Midlawn $^{\mathrm{x}}$ & 6 & $\ldots{ }^{\mathrm{y}}$ \\
\hline OKS 91-4 & 6 & 28 \\
\hline Sundevil & 5 & 34 \\
\hline OKS 91-3 & 5 & 49 \\
\hline OKS 89-3 & 6 & 23 \\
\hline OKS $91-12$ & 6 & 13 \\
\hline $\begin{array}{l}\text { African } \\
\text { bermudagrass }\end{array}$ & 6 & 14 \\
\hline Guymon & 6 & 15 \\
\hline $\operatorname{LSD}(0.05)$ & 1 & 20 \\
\hline
\end{tabular}

${ }^{\text {w }}$ On a scale of 1 to 9 , with $1=$ dead or dormant turf and $9=$ completely green turf.

${ }^{x}$ Midfield, Midlawn, and Tifton 10 were vegetatively propagated. The remaining entries were seed-propagated.

y Winter kill evaluations were not taken for bermudagrasses that were vegetatively propagated.

${ }^{\mathrm{z}} \mathrm{OKS}=$ Oklahoma State University experimental seed-propagated entries. 
Table 4. Severity of spring dead spot for bermudagrass entries in 1995 and 1996 following inoculation with Ophiosphaerella herpotricha in 1994 in Oklahoma

\begin{tabular}{|c|c|c|}
\hline \multirow[b]{2}{*}{ Entry } & \multicolumn{2}{|c|}{$\begin{array}{c}\text { Average diseased area } \\
\left(\mathrm{cm}^{2}\right)\end{array}$} \\
\hline & 4/18/95 & $4 / 18 / 96$ \\
\hline Common & 230 & 1,810 \\
\hline Poco Verde & 262 & 1,749 \\
\hline Jackpot & 219 & 1,712 \\
\hline Sonesta & 197 & 1,658 \\
\hline Tifton $10^{y}$ & 180 & 1,541 \\
\hline Primavera & 179 & 1,433 \\
\hline $\mathrm{OKS}^{\mathrm{z}}$ 91-1 & 194 & 1,432 \\
\hline NuMex Sahara & 165 & 1,344 \\
\hline Pyramid & 195 & 1,288 \\
\hline Cheyenne & 185 & 1,091 \\
\hline Tropica & 137 & 1,034 \\
\hline OKS 91-2 & 246 & 971 \\
\hline $\mathrm{C}^{2}$ & 156 & 755 \\
\hline OKS 91-6 & 176 & 653 \\
\hline Mirage & 99 & 601 \\
\hline Ft. Reno & 64 & 552 \\
\hline Midfield $y$ & 63 & 473 \\
\hline OKS 91-13 & 107 & 396 \\
\hline Midlawn ${ }^{y}$ & 102 & 360 \\
\hline OKS 91-4 & 155 & 353 \\
\hline Sundevil & 47 & 316 \\
\hline OKS 91-3 & 95 & 303 \\
\hline OKS 89-3 & 126 & 239 \\
\hline OKS 91-12 & 105 & 218 \\
\hline $\begin{array}{l}\text { African } \\
\text { bermudagrass }\end{array}$ & 103 & 140 \\
\hline Guymon & 80 & 121 \\
\hline LSD $(0.05)$ & 87 & 538 \\
\hline \multicolumn{3}{|c|}{$\begin{array}{l}{ }^{x} \text { Area of inoculation (area of cup cutter) }=84 \\
\mathrm{~cm}^{2} .\end{array}$} \\
\hline \multicolumn{3}{|c|}{$\begin{array}{l}\text { y Midfield, Midlawn, and Tifton } 10 \text { were vege- } \\
\text { tatively propagated. The remaining entries } \\
\text { were seed-propagated. }\end{array}$} \\
\hline
\end{tabular}

The influence of cold temperatures on disease development and severity is consistent with observations that SDS only develops after winter dormancy and cultivars with increased winter hardiness are less susceptible to the disease $(1,2,11,16)$. Gatschet et al. $(6,7)$ found higher levels of a chitinase protein in crown tissue of the cold hardy Midiron bermudagrass cultivar compared with the less cold hardy Tifgreen following cold acclimation. Chitinases are thought to function in disease resistance by attacking cell walls of invading fungal pathogens and signaling plant defense response (8). Furthermore, several chitinases possess antifreeze activity, which is thought to protect sensitive tissue from damage at near-freezing temperatures (9). Chitinase involvement in both disease and cold resistance suggests that this protein may partially explain the correlation between bermudagrass cold hardiness and resistance to SDS in the field.

Overall, the bermudagrass entries found to have the smallest area of SDS also had the greatest number of live shoots within each area. Therefore, these data indicate that disease area measurements together
Table 5. Least squares means ${ }^{\mathrm{x}}$ representing the number of live shoots per diseased area for bermudagrass entries in 1995 and 1996 following inoculation with Ophiosphaerella herpotricha in 1994 in Oklahoma

\begin{tabular}{|c|c|c|c|c|c|}
\hline \multirow[b]{3}{*}{ Entry } & \multirow{2}{*}{\multicolumn{2}{|c|}{$\begin{array}{l}\text { No. of live shoots/ } \\
\text { diseased area }\end{array}$}} & \multirow[b]{2}{*}{1995} & \multicolumn{2}{|c|}{1994} \\
\hline & & & & Winter kill & Green up \\
\hline & 4/18/95 & 4/18/96 & Diseased area & $r \quad 0.56$ & \\
\hline $\begin{array}{l}\text { African } \\
\text { bermudagrass }\end{array}$ & $5.9 \mathrm{a}$ & $8.4 \mathrm{a}$ & & $\begin{array}{ll}P & 0.0001\end{array}$ & 0.002 \\
\hline $\begin{array}{l}\text { bermudagrass } \\
\text { Midlawn }^{y}\end{array}$ & $2.6 \mathrm{~b}$ & $3.0 \mathrm{~b}$ & $\begin{array}{l}\text { Live shoots/ } \\
\text { diseased area }\end{array}$ & $\begin{array}{ll}r & -0.42 \\
P & 0.0003\end{array}$ & $\begin{array}{l}-0.64 \\
0.0001\end{array}$ \\
\hline OKS $89-3^{z}$ & $1.0 \mathrm{~cd}$ & $2.5 \mathrm{bc}$ & & & \\
\hline OKS 91-13 & $1.1 \mathrm{~cd}$ & $2.4 \mathrm{bc}$ & Live shoots ${ }^{\mathrm{z}}$ & $r-0.26$ & -0.61 \\
\hline Mirage & $1.9 \mathrm{bc}$ & $2.3 \mathrm{bc}$ & diseased area & $P \quad 0.032$ & 0.0001 \\
\hline
\end{tabular}

$\begin{array}{lll}\text { OKS 91-12 } & 1.6 \mathrm{bc} & 2.3 \mathrm{bc} \\ \text { Midfieldy } & 1.4 \mathrm{c} & 2.2 \mathrm{bc}\end{array}$

Ft. Reno $\quad 0.9 \mathrm{~cd} \quad 2.2 \mathrm{bc}$

Sundevil $\quad 0.7 \mathrm{~cd} \quad 1.8 \mathrm{c}$

$\begin{array}{lll}\text { OKS 91-4 } & 0.3 \mathrm{~cd} & 1.8 \mathrm{c}\end{array}$

Guymon $\quad 0.7 \mathrm{~cd} \quad 1.7 \mathrm{~cd}$

OKS 91-3 $\quad 1.1 \mathrm{~cd} \quad 1.6 \mathrm{~cd}$

$\begin{array}{lll}\text { OKS 91-6 } & 0.1 \mathrm{~d} & 0.8 \mathrm{~d}\end{array}$

$\begin{array}{lll}\text { OKS 91-2 } & 0.3 \mathrm{~cd} & 0.7 \mathrm{~d}\end{array}$

$\begin{array}{lll}\text { Pyramid } & 0.3 \mathrm{~cd} & 0.7 \mathrm{~d}\end{array}$

$\begin{array}{lll}\text { Cheyenne } & 0.3 \mathrm{~cd} & 0.7 \mathrm{~d}\end{array}$

Tifton $10^{\mathrm{y}} \quad 0.4 \mathrm{~cd} \quad 0.7 \mathrm{~d}$

Tropica $\quad-0.1 \mathrm{~d} \quad 0.6 \mathrm{~d}$

Jackpot $\quad 0.0 \mathrm{~d} \quad 0.5 \mathrm{~d}$

NuMex Sahara $\quad 0.1 \mathrm{~d} \quad 0.5 \mathrm{~d}$

$\begin{array}{lll}\text { Primavera } & 0.2 \mathrm{~d} & 0.4 \mathrm{~d}\end{array}$

Common $\quad-0.1 \mathrm{~d} \quad 0.3 \mathrm{~d}$

$\begin{array}{lll}\text { OKS 91-1 } & 0.3 \mathrm{~cd} & 0.3 \mathrm{~d}\end{array}$

Poco Verde $\quad-0.2 \mathrm{~d} \quad 0.2 \mathrm{~d}$

$\begin{array}{lll}\text { Sonesta } & 0.2 \mathrm{~d} & 0.2 \mathrm{~d}\end{array}$

$\begin{array}{lll}\mathrm{C}^{2} & 0.6 \mathrm{~cd} & 0.1 \mathrm{~d}\end{array}$

${ }^{x}$ Least squares means within a column followed by different letters are significantly different $($ alpha $=0.05)$. Covariate $=$ shoot density measured in July 1996.

y Midfield, Midlawn, and Tifton 10 were vegetatively propagated. The remaining entries were seed-propagated.

${ }^{\mathrm{z}} \mathrm{OKS}=$ Oklahoma State University experimental seed-propagated entries.

with live shoot counts within spring dead spots are useful indicators of the relative degree of resistance among bermudagrass cultivars. We are continuing to evaluate bermudagrass entries for resistance to SDS causal agents and to determine the molecular mechanism(s) responsible for SDS resistance and cold hardiness in bermudagrass. In summary, our results indicate that use of resistant bermudagrass cultivars may be an effective management strategy to reduce severity of SDS caused by $O$. herpotricha.

\section{ACKNOWLEDGMENTS}

This paper reports research supported by a grant from the U.S. Golf Association, the Golf Course Superintendents Association of America, the Heart of America and Kansas Golf Course Superintendents Associations, and the Kansas Turfgrass and Oklahoma Turfgrass Research Foundations.

\section{LITERATURE CITED}

1. Anderson, J. A., Kenna, M. P., and Taliaferro, C. M. 1988. Cold hardiness of 'Midiron' and 'Tifgreen' bermudagrass. HortScience 23:748-750.

2. Anderson, J. A., Taliaferro, C. M., and Martin, D. L. 1993. Evaluating freeze
Table 6. Pearson correlation coefficients $(r)$ and probability $(P)$ values for the effects of bermudagrass winter kill and spring green up in 1994 on spring dead spot disease severity in 1995 in Oklahoma

${ }^{\mathrm{z}}$ Adjusted for shoot density measured in July 1996.

resistance of bermudagrass in a controlled environment. HortScience 28:955.

3. Crahay, J. N., Dernoeden, P. H., and O'Neill, N. R. 1988. Growth and pathogenicity of Leptosphaeria korrae in bermudagrass. Plant Dis. 72:945-949.

4. Dernoeden, P. H., Crahay, J. N., and Davis, D. B. 1991. Spring dead spot and bermudagrass quality as influenced by nitrogen source and potassium. Crop Sci. 31:1674-1680. 1985. Leptosphaeria korrae, a cause of the spring dead spot disease of bermudagrass in California. Plant Dis. 69:235-237.

6. Gatschet, M. J., Taliaferro, C. M., Anderson, J. A., Porter, D. R., and Anderson, M. P. 1994. Cold acclimation and alteration in protein synthesis in bermudagrass crowns. J. Am. Soc. Hortic. Sci. 119:477-480.

7. Gatschet, M. J., Taliaferro, C. M., Porter, D. R., Anderson, M. P., Anderson, J. A., and Jackson, K. W. 1996. A cold-regulated protein from bermudagrass crowns is a chitinase. Crop Sci. 36:712-718.

8. Graham, L. S., and Sticklen, M. B. 1994 Plant chitinases. Can. J. Bot. 72:1057-1083.

9. Hon, W.-C., Griffith, M., Mlynarz, A., Kowk, Y. C., and Yang, D. S. C. 1995. Antifreeze proteins of winter rye are similar to pathogenesis-related proteins. Plant Physiol. 109:879-889.

10. Lucas, L. T. 1980. Control of spring dead spot of bermudagrass with fungicides in North Carolina. Plant Dis. 64:868-870.

11. Lucas, L. T. 1980. Spring deadspot of bermudagrass. Pages 183-187 in: Advances in Turfgrass Pathology. B. G. Joyner and P. O. Larsen, eds. Harcourt Brace Jovanovich, Duluth, MN.

12. Nus, J. L., and Shashikumar, K. 1993. Fungi associated with spring dead spot reduces freezing resistance in bermudagrass. HortScience 28:306-307.

13. Smiley, R. W., Dernoeden, P. H., and Clarke, B. B. 1992. Compendium of Turfgrass Diseases. 2nd ed. American Phytopathological Society, St. Paul, MN.

14. Smith, A. M. 1971. Spring dead spot of couchgrass in New South Wales. J. Sports Turf Res. Inst. 47:54-59.

15. Steel, R. G. D., and Torrie, J. H. 1980. Principles and Procedures of Statistics-A Biometrical Approach, McGraw-Hill, New York.

16. Tisserat, N. A., Pair, J. C., and Nus, A. 1989. Ophiosphaerella herpotricha, a cause of spring dead spot of bermudagrass in Kansas. Plant Dis. 73:933-937.

17. Walker, J., and Smith, A. M. 1972. Leptosphaeria narmari and $L$. korrae sp. nov., two long-spored pathogens of grasses in Australia. Trans. Br. Mycol. Soc. 58:459-466.
5. Endo, R. M., Ohr, H. D., and Krausman, E. M 